\title{
Aquatic Hyphomycetes in the Parque Estadual das Fontes do Ipiranga - PEFI, São Paulo, Brazil
}

\author{
IRACEMA HELENA SCHOENLEIN-CRUSIUS ${ }^{1,3}$, \\ CAROLINA GASCH MOREIRA ${ }^{2}$ and DENISE DE CAMPOS BICUDO ${ }^{1}$
}

(received: April 24, 2008; accepted: April 01, 2009)

\begin{abstract}
Aquatic Hyphomycetes in the Parque Estadual das Fontes do Ipiranga - PEFI, São Paulo, Brazil). In the State Park Parque Estadual das Fontes do Ipiranga - PEFI, located in the city of São Paulo, samples of submerged mixed leaf litter were collected monthly from 10 sites with different levels of eutrophication, from October 2003 to April 2005. Some abiotic factors, such as $\mathrm{pH}$, temperature, conductivity and dissolved oxygen were simultaneously measured in $20 \mathrm{~cm}$ deep water at each site. The leaf litter samples were washed in laboratory, cut into $1 \mathrm{~cm}^{2}$ pieces and incubated in Petri dishes containing distilled sterile water for five to seven days at $15{ }^{\circ} \mathrm{C}$ to $20^{\circ} \mathrm{C}$. Twenty-four aquatic Hyphomycete species were identified, with predominance of Anguillospora crassa Ingold, Lunulospora curvula Ingold, Tetrachaetum elegans Ingold and Camposporium pellucidum (Grove) Hughes. First reports for South America are: Anguillospora filiformis Greathead, Dendrospora erecta Ingold and Pyramidospora casuarinae Nilsson. These species, as well as Tetracladium setigerum (Grove) Ingold, Tricladium splendens Ingold and Varicosporium elodeae Kegel, are reported for the first time in Brazil. According to the multivariate analysis, the occurrence of the aquatic Hyphomycetes was mainly influenced by the trophic level of the aquatic environments.
\end{abstract}

Key words - biodiversity, eutrophication, fungal diversity, Ingoldian fungi

RESUMO - (Hyphomycetes aquáticos no Parque Estadual das Fontes do Ipiranga, PEFI, São Paulo, Brasil). No Parque Estadual das Fontes do Ipiranga, localizado na cidade de São Paulo, amostras de folhedo misto submerso foram coletadas mensalmente, de outubro de 2003 a abril de 2005, em 10 locais com diferentes níveis de eutrofização. Alguns fatores abióticos, tais como $\mathrm{pH}$, temperatura, condutividade e oxigênio dissolvido, foram concomitantemente medidos a $20 \mathrm{~cm}$ de profundidade na água de cada local de coleta. No laboratório as amostras de folhedo foram lavadas, cortadas em pedaços de $1 \mathrm{~cm}^{2} \mathrm{e}$ incubadas em placas de Petri contendo água destilada esterilizada, durante cinco a sete dias de $15^{\circ} \mathrm{C}$ a $20^{\circ} \mathrm{C}$. Vinte e quatro Hyphomycetes aquáticos foram identificados, com predomínio de Anguillospora crassa Ingold, Lunulospora curvula Ingold, Tetrachaetum elegans Ingold e Camposporium pellucidum (Grove) Hughes. São citados pela primeira vez para a América do Sul: Anguillospora filiformis Greathead, Dendrospora erecta Ingold e Pyramidospora casuarinae Nilsson. Estes somados a Tetracladium setigerum (Grove) Ingold, Tricladium splendens Ingold e Varicosporium elodeae Kegel, são citados pela primeira vez para o Brasil. De acordo com a análise multivariada a ocorrência dos Hyphomycetes aquáticos foi influenciada principalmente pelo nível trófico dos ambientes aquáticos.

Palavras-chave - biodiversidade, diversidade de fungos, eutrofização, fungos "ingoldianos"

\section{Introduction}

Anamorphic fungi, also known as imperfect fungi, mitosporic fungi or representatives of the Deuteromycota, include the Hyphomycetes, which are mainly characterized by the production of a-sexual spores (conidia), either contained in sporodochia or freely dispersed in the environment (Alexopoulos et al. 1996). Specifically in the case of the aquatic Hyphomycetes, spores have hydrodynamic star-like,

1. Instituto de Botânica, Caixa Postal 3005, 01061-970 São Paulo, Brazil.

2. Universidade de Santo Amaro, Unisa, Rua Profo Enéias de Siqueira Neto 340, 04829-300 São Paulo, Brazil.

3. Autor para correspondência: iracema@crusius.com.br sigmoid or spherical shapes easily trapped on the surface of leaf litter submerged in streams, ponds or in interstitial soil waters (Dix \& Webster 1995). Because of the conidial shape, the aquatic Hyphomycetes are known as tetraradiate fungi and also "Ingoldian fungi" in honor of Prof. Dr. C. T. Ingold, who was one of the most important pioneers in the study of this fungal group (Marvanová 1997).

Mainly in lotic environments, the aquatic Hyphomycetes have been considered the most active fungi in the decomposition of submerged leaf litter, increasing the palatability of decaying leaves to invertebrates, due to the accumulation of nutrients on colonized substrates. It has been assumed that modifications in the richness or diversity of the aquatic Hyphomycetes may have a direct impact on the trophic 
chain and nutrient cycling in the aquatic environment (Bärlocher 1992).

Fast running, well aerated cold streams have been considered ideal for the development of aquatic Hyphomycetes (Ingold 1975), but their presence in reservoirs, groundwater and even strongly polluted waters (Sladeckova 1963, Suberkropp et al. 1988, Au et al. 1992) indicate a broader distribution in temperate climates as well as in the tropics. The diversity of the aquatic Hyphomycetes is influenced by the features of the substrates, the changes of abiotic factors in the water bodies and complex interactions among climatic and limnological factors (Bärlocher 1992, Marvanová 1997).

Almost all Brazilian sites where the aquatic Hyphomycetes have been studied are situated in the state of São Paulo. Collections were made in streams, medium size rivers, waterfalls, lakes and reservoirs under subtropical climatic conditions and around 60 taxa were obtained. Reviews about the diversity of aquatic Hyphomycetes in South America can be found in Schoenlein-Crusius \& Grandi (2003) and, about their distribution in the tropics, in Schoenlein-Crusius \& Malosso (2007).

The aquatic Hyphomycetes were first mentioned in Brazil during the fungal succession on decomposing Ficus microcarpa L. f. leaves submerged in the highly eutrophic reservoir Garças Lake located in the Parque Estadual das Fontes do Ipiranga (Schoenlein-Crusius \& Milanez 1989), whose diversity of Ingoldian fungi in several types of aquatic environments will be presented in this paper.

The Parque Estadual das Fontes do Ipiranga - PEFI covers 526.38 ha with remaining Atlantic rainforest, at an altitude of 770 to $825 \mathrm{~m}$ (Nastri et al. 1992). The area is located in the southeast region of the city of São Paulo, in the State of São Paulo, between $23^{\circ} 38^{\prime} 08^{\prime \prime} \mathrm{S}-23^{\circ} 40^{\prime} 18^{\prime \prime} \mathrm{S}$ and $46^{\circ} 36^{\prime} 48^{\prime \prime} \mathrm{W}$ $46^{\circ} 38^{\prime} 00^{\prime \prime} \mathrm{W}$ (Fernandes et al. 2002), and is influenced by the typical pollution of an urban area caused by car traffic, industries, sewage, etc. There are streams, canals, little waterfalls and reservoirs with different degrees of eutrophication, making the PEFI area an interesting site to compare the diversity of organisms under various conditions (Bicudo et al. 2002). According to Bicudo et al. (2002) the cryptogamic flora is mentioned in only 17 papers, whereof only $15 \%$ referred to fungi. In the aquatic environments in the PEFI area, only taxonomic surveys of zoosporic fungi have been conducted until now (Milanez \& Trufem 1984, Milanez et al. 1996, PiresZottarelli et al. 1996, Pires-Zottarelli \& Rocha 2007).
The present study aimed to evaluate aquatic Hyphomycetes diversity in the PEFI area, comparing fungal occurrences as they relate to seasons and eutrophication levels of water bodies. In addition, the interaction between fungal occurrences and some abiotic factors in the water during the collections were also analyzed.

\section{Materials and methods}

Collection sites and months - Rainfall meteorological data $(\mathrm{mm})$ and air temperature $\left({ }^{\circ} \mathrm{C}\right)$, formerly registered in the Parque Estadual das Fontes do Ipiranga, characterize the period between April to September as cold and dry. January to March and October to December comprise a sultry period. Average air temperature usually stays at around $19.1{ }^{\circ} \mathrm{C}$, whereas annual rainfall approximates $1539 \mathrm{~mm}$ (Santos \& Funari 2002). According to meteorological data issued by the Technical Section for Meteorological Services of the Instituto de Astronomia, Geofísica e Ciências Atmosféricas of the University of São Paulo, during the studied period, the air temperature varied from $15.3{ }^{\circ} \mathrm{C}$ (July 2004) to $22.0^{\circ} \mathrm{C}$ (January 2005) and the total monthly rainfall varied between $2.8 \mathrm{~mm}$ (August 2004) to $385.8 \mathrm{~mm}$ (January 2004), confirming the continuity of the seasonal characteristics of the reservation.

Almost all water bodies in the PEFI reserve are surrounded by dense rainforest, receiving regular input of senescent and dead leaves. The annual litter production reaches $9.3 \mathrm{t} \mathrm{MS} \mathrm{ha}^{-1}$, with $70 \%$ of leaves (Moraes 2002), originated mainly from Myrtaceae, Fabaceae, Lauraceae and Melastomataceae trees, and Asteraceae, Poaceae and Fabaceae herbs, which are the most representative families of the phanerogamic flora in the PEFI reserve (Barros et al. 2002).

Since 1997, water quality of PEFI's reservoirs and of some streams in it has been monitored monthly (Bicudo et al. 2002), allowing their classification according to the trophic condition.

In September 2003, ten collection sites were chosen according to their type of aquatic environment (lotic or lentic system) and trophic condition. The geographical situation of each site was defined by an Global Positioning System Garmin type 12 equipment (table 1).

Collections - At each of the ten collection sites, two samples of mixed submerged leaf litter (approx. $50 \mathrm{~g}$ ) were taken monthly from the margins, at a maximum depth of $40 \mathrm{~cm}$. In addition, some abiotic factors such as temperature, dissolved oxygen, conductivity and $\mathrm{pH}$ of the water at each collection site were measured with a water quality checker $-\mathrm{U}_{10}$ equipment from Horiba.

Isolation and identification of aquatic Hyphomycetes - The procedures to obtain, isolate and identify aquatic Hyphomycetes followed Ingold's (1975) and Marvanova's 
Table 1. Names, geographical localization, limnological features and vegetation of the collection sites in the Parque Estadual das Fontes do Ipiranga - PEFI, São Paulo.

\begin{tabular}{lll}
\hline Collection sites & $\begin{array}{l}\text { Geographical } \\
\text { localization }\end{array}$ & Limnological features and vegetation \\
\hline
\end{tabular}

1. Lago das Garças

2. Stream in riparian forest

3. Canal

4. Lago do Castelinho

5. Drainage canal

6. Lago da Roda

7. Lago dos Bugios

8. Fountain

9. Lago das Ninféias

10. Artificial waterfall $22^{\circ} 27^{\prime} 186^{\prime \prime} \mathrm{S}$ and 4731'669" W

$22^{\circ} 27^{\prime} 186^{\prime \prime} \mathrm{S}$ and $47^{\circ} 31^{\prime} 669^{\prime \prime} \mathrm{W}$

$23^{\circ} 38^{\prime} 420^{\prime \prime} \mathrm{S}$ and $46^{\circ} 37^{\prime} 569^{\prime \prime} \mathrm{W}$

$23^{\circ} 38^{\prime} 374^{\prime \prime}$ S and $46^{\circ} 37^{\prime} 125^{\prime \prime} \mathrm{W}$

$23^{\circ} 38^{\prime} 327^{\prime \prime} \mathrm{S}$ and 463' 119 ' W

$23^{\circ} 38^{\prime} 315^{\prime \prime} \mathrm{S}$ and $46^{\circ} 37^{\prime} 154^{\prime \prime} \mathrm{W}$

$23^{\circ} 38^{\prime} 266^{\prime \prime} \mathrm{S}$ and 463' $214^{\prime \prime} \mathrm{W}$

$23^{\circ} 38^{\prime} 285^{\prime \prime} \mathrm{S}$ and $46^{\circ} 37^{\prime} 235^{\prime \prime} \mathrm{W}$

$23^{\circ} 38^{\prime} 299^{\prime \prime} \mathrm{S}$ and 463' $299^{\prime \prime} \mathrm{W}$

$23^{\circ} 38^{\prime} 306^{\prime \prime} \mathrm{S}$ and $46^{\circ} 37^{\prime} 328^{\prime \prime} \mathrm{W}$
Eutrophic lentic system, with high incidence of cyanobacteria, surrounded by Atlantic rainforest.

Oligotrophic lotic system in a riparian forest.

Eutrophic lotic system in a grassy field far from forest vegetation.

Meso-oligotrophic lentic system, surrounded by dense Atlantic rainforest.

Mesotrophic lotic system in a riparian forest.

Mesotrophic lentic system, surrounded by Atlantic rainforest.

Mesotrophic lentic system, surrounded by Atlantic rainforest.

Oligotrophic fountain surrounded by Atlantic rainforest.

Mesotrophic lentic system, with high incidence of Nymphaea spp.

Mesotrophic artificial ornamental waterfall far from forest vegetation.
(1997) recommendations. In the laboratory, the leaves were vigorously washed with tap water to clean debris from the leaf surface. The leaves were then cut into pieces of approximately $1 \mathrm{~cm}^{2}$, placed in Petri dishes containing sterile water and incubated at the temperature of $15^{\circ} \mathrm{C}$ to $20^{\circ} \mathrm{C}$ during 5 to 7 days. The fragments were placed on slides, covered with distilled water or cotton blue with $2 \%$ lactophenol, and observed under a light microscope. Once the development of conidiophores and conidia were detected, structures were measured, drawings were made with a camera lucida, and taxonomical keys were consulted to identify species by their taxonomical features (Nilsson 1964, Ingold 1975, Subramanian 1983, Bärlocher 1992, Marvanová 1997).

Statistical methods - To compare the aquatic fungi obtained in different months and collection sites, the similarity index of Sörensen (S) was used, calculated by the formula: $\mathrm{S}=2 \mathrm{xc} / \mathrm{a}+\mathrm{b}$, where $\mathrm{a}$ is the total number of fungal taxa in a given collection, $b$ is the total number of fungal taxa in the collection to be compared and $\mathrm{c}$ is the number of taxa that are common in the two compared collections. The similarity is expressed in percentages multiplying $\mathrm{S} \times 100$ (MüllerDombois \& Ellenberg 1974).
A principal component analysis was conducted to verify the existence of interactions between the abiotic factors and fungal occurrences, using statistical software FITOPAC and PC-ORD.

\section{Results and discussion}

The diversity of aquatic Hyphomycetes - Twenty-four taxa of aquatic Hyphomycetes were present in 193 observations (table 2). All taxa are considered typical Ingoldian fungi, which means truly aquatic, with hydrodynamic shapes (Marvanová 1997, Bärlocher 1992), except Fusarium aquaeductum, which has been rarely observed on submerged decomposing leaves. The predominant aquatic Hyphomycetes were Anguillospora crassa and Lunulospora curvula (table 2), observed during 13 months, totally 31 records, as well as Tetrachaetum elegans observed during 10 months, totally 32 records. Anguillospora longissima and Camposporium pellucidum were also frequently observed, but in fewer months. These taxa have been 


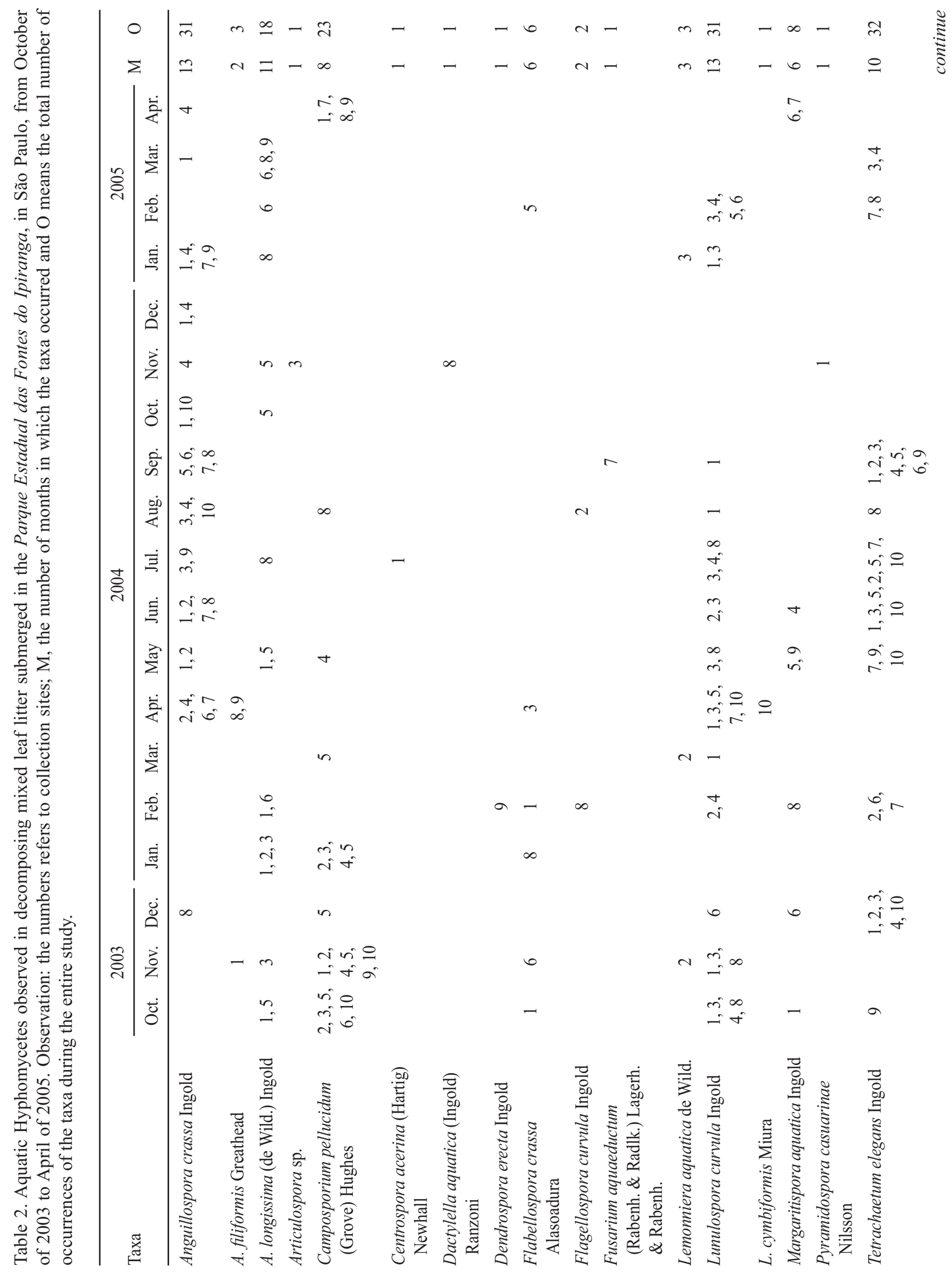




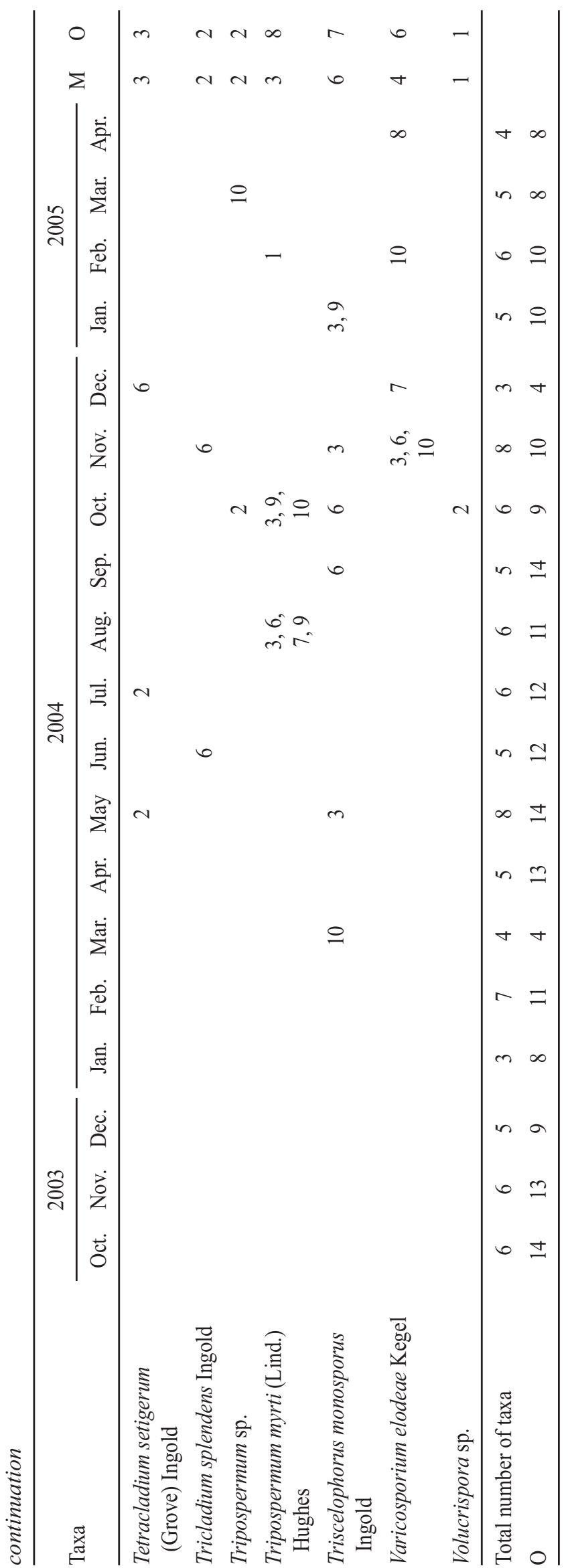

considered common in tropical waters (SchoenleinCrusius \& Malosso 2007), and have already been reported for the Atlantic rainforest (Schoenlein-Crusius \& Milanez 1998) and for the cerrado, a Brazilian savannah (Schoenlein-Crusius 2002).

Among the mycota (table 2), only A. longissima, Lunulospora sp., Tetrachaetumelegans and Lemonniera aquatica were previously observed during the fungal succession on leaves of Ficus microcarpa submerged in the Lago das Garças (Schoenlein-Crusius \& Milanez 1989). Therefore, the present study adds 21 taxa of aquatic Hyphomycetes to the mycota of the PEFI reserve. Anguillospora filiformis, Dendrospora erecta and Pyramidospora casuarinae are cited for the first time in South America. These taxa, together with Tetracladium setigerum, Tricladium splendens and Varicosporium elodeae, are recorded for the first time in Brazil. In addition, Anguillospora filiformis, Centrospora acerina, Lunulospora cymbiformis and Pyramidospora casuarinae, according to Ingold (1975), are not common in the tropics. Based on the combined results of several worldwide studies, about 100 anamorphic genera and 300 species of aquatic Hyphomycetes are known today (Kirk et al. 2001). In comparison to temperate climates, where the number of taxa of aquatic Hyphomycetes usually reaches 70 a 80, the number of taxa reported for the PEFI reservation seems low. However, keeping in mind that until 2003, based on 20 papers, only around 60 taxa were known in Brazil (Schoenlein-Crusius \& Grandi 2003), the contribution of the present study to the knowledge of diversity of the aquatic Hyphomycetes seems more impressive.

The occurrence of aquatic Hyphomycetes according to months and climatic seasons - The highest number of taxa of aquatic Hyphomycetes - eight - was observed in May and November 2004, and the lowest - three - in January and December 2004 (table 2). The total number of records, calculated by the addition of taxa occurrences observed in samples taken from all collection sites, ranged from 14 in October 2003, April and September 2004 to four in March and December 2004, showing no clear connection between fungal occurrences and month of collection.

Although the present study was conducted in aquatic environment, the Christensen's (1989) assumption for soil fungi, that similarities above $70 \%$ would be considered high in tropical ecosystems, may be applied to compare the mycota observed in each month (table 3 ). According to these criteria, only 


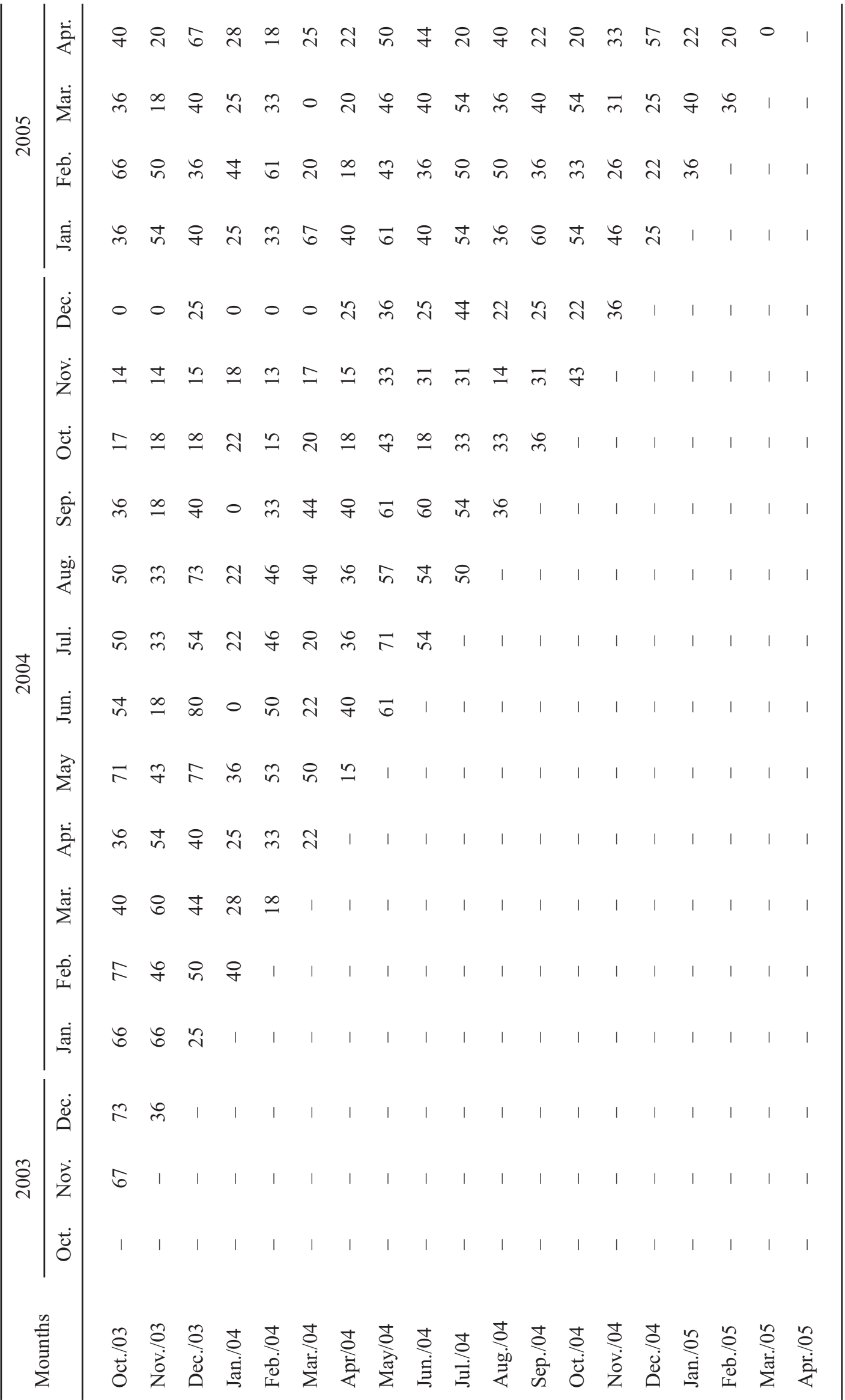


seven comparisons resulted in high similarity indexes, nine comparisons did not show any similarity, and the remaining indices showed low similarity, demonstrating that the composition of the mycota tended to vary each month.

Monthly occurrences of the aquatic Hyphomycetes were clustered considering that the entire collection period underwent two hot rainy seasons and one cold dry season (table 4). The total numbers of taxa varied little between seasons, from 12 to 18 , unlike the total number of fungal occurrences, which ranged from 40 to 52 .

Anguillospora crassa, A. longissima, Flabellospora crassa, Lunulospora curvula,

Table 4. Taxa of aquatic Hyphomycetes observed in the decomposing leaf litter submerged in the Parque Estadual das Fontes do Ipiranga in São Paulo, from October/2003 to April/2005, clustered according to the climatic seasons. Observations: the numbers refers to the collection sites where the taxa occurred.

\begin{tabular}{|c|c|c|c|}
\hline \multirow[b]{2}{*}{ Taxa of aquatic Hyphomycetes } & \multicolumn{3}{|c|}{ Seasons } \\
\hline & $\begin{array}{l}\text { Warm and rainy } \\
2003 / 2004\end{array}$ & $\begin{array}{l}\text { Cold and dry } \\
\qquad 2004\end{array}$ & $\begin{array}{l}\text { Warm and rainy } \\
2004 / 2005\end{array}$ \\
\hline Anguillospora crassa Ingold & 8 & $\begin{array}{c}2,3,4,5,6 \\
7,8,9,10\end{array}$ & $1,10,4,7,9$ \\
\hline A. filiformis Greathead & 1 & $1,8,9$ & 0 \\
\hline A. longíssima (de Wild.) Ingold & $1,5,3,2,6$ & $1,5,8$ & $5,6,8,9$ \\
\hline Articulospora sp. & 0 & 0 & 3 \\
\hline Camposporium pellucidum (Grove) Hughes & $\begin{array}{l}1,2,3,4 \\
5,6,9,10\end{array}$ & 4,8 & $1,7,8,9$ \\
\hline Centrospora acerina (Hartig) Newhall & 0 & 1 & 0 \\
\hline Dactylella aquatica (Ingold) Ranzoni & 0 & 0 & 8 \\
\hline Dendrospora erecta Ingold & 9 & 9 & 0 \\
\hline Flabellospora crassa Alasoadura & $1,6,8,1$ & 3 & 5 \\
\hline Flagellospora curvula Ingold & 8 & 2 & 0 \\
\hline $\begin{array}{l}\text { Fusarium aquaeductuum (Rabenh. \& Radlk.) Lagerh. } \\
\text { \& Rabenh. }\end{array}$ & 0 & 7 & 0 \\
\hline Lemonniera aquatica de Wild. & 2 & 0 & 3 \\
\hline Lunulospora curvula Ingold & $1,2,3,4,6,8$ & $\begin{array}{l}1,3,5,7 \\
10,8,2,4\end{array}$ & $1,3,4,5,6$ \\
\hline L. cymbiformis Miura & 0 & 10 & 0 \\
\hline Margaritispora aquatica Ingold & $1,6,8$ & $4,5,9$ & 6,7 \\
\hline Pyramidospora casuarinae Nilsson & 0 & 0 & 1 \\
\hline Tetrachaetum elegans Ingold & $\begin{array}{l}1,2,3,4 \\
6,7,9,10\end{array}$ & $\begin{array}{l}1,2,3,4,5 \\
6,9,7,10,8\end{array}$ & $3,4,7,8$ \\
\hline Tetracladium setigerum (Grove) Ingold & 0 & 2 & 6 \\
\hline Tricladium splendens Ingold & 0 & 6 & 0 \\
\hline Tripospermum sp. & 0 & 0 & 10 \\
\hline Tripospermum myrti (Lind.) Hughes & 0 & $3,6,7,9$ & $1,3,9,10,6,7$ \\
\hline Triscelophorus monosporus Ingold & 10 & 3,6 & $3,6,9,10$ \\
\hline Varicosporium elodeae Kegel & 0 & 0 & $3,6,10,7,8$ \\
\hline Volucrispora sp. & 0 & 0 & 2 \\
\hline Total number of taxa & 12 & 17 & 17 \\
\hline Total number of occurrences & 40 & 52 & 47 \\
\hline
\end{tabular}


Camposporium pellucidum, Margaritispora aquatica and Tetrachaetum elegans tend to occur in any season (table 4), whereas Anguillospora filiformis, Dendrospora erecta, Flagellospora curvula, Tetracladium setigerum, Tripospermum myrtii and Triscelophorus monosporus presented the tendency to occur in both seasons, not in any one. Articulospora sp., Dactylella aquatica, Lemonniera aquatica, Pyramidospora casuarinae, Tripospermum sp., Varicosporium elodeae and Volucrispora sp. were more frequent in hot rainy seasons, while Centrospora acerina, Fusarium aquaeductum, Lunulospora cymbiformis and Tricladium splendens occurred more often in cold dry seasons.

Comparing the fungal community by the Sörensen index, it was verified that the mycota observed in the first hot rainy season and the one in the next cold dry season were $76 \%$ similar. The comparison between the last mycota and the one observed in the hot rainy season, from October 2004 to March 2005 revealed a similarity of $57 \%$, and the mycota of the first and the second hot rainy season presented $60 \%$ of similarity. Regardless of time period, the aquatic Hyphomycetes had a greater tendency to occur in the two climatic seasons than exclusively in one or other season, reinforcing the cosmopolitan character of these fungi.

Indeed, aquatic Hyphomycetes are considered cosmopolitans in their distribution, being observed from the Artic Pole to the Equator Line (Webster \& Descals 1981). On the other hand, species such as Flagellospora curvula, Lemonniera aquatica, Lemonniera centrosphaera Marvanová and Alatospora acuminate Ingold are considered to predominate in the northern hemisphere, whereas in the tropics Lunulospora curvula, Triscelophorus acuminatus Ingold and Ingoldiella hamata D. E. Shaw are more common (Ingold 1975). Optimal temperatures for growth and sporulation have been correlated with the geographical distribution of the fungi, possibly justifying their predominance in one or other climates (Bärlocher 1992).

As soon as leaves submerge in a stream, fungal activity or the number of conidia may initially increase sharply and then decline, sometimes causing nondetection of some species (Bärlocher 1992). In addition, the behavior of the mycota seems to be influenced by the type of ecosystem, leading to conflicting results. Lower numbers of species in warm seasons were reported by Iqbal \& Webster (1977) and Ferreira et al. (1981), while Del Frate \& Caretta (1983) did not observe seasonal variations of the species richness, and
Iqbal \& Bhatty (1979) detected an increase of species variety after heavy rainfalls.

Tropical streams usually receive twice the quantity of plant debris from terrestrial origin than the ones in temperate climates. In some forests, the decomposition of all this organic matter is accomplished by invertebrates during dry seasons. In other forests, leaves accumulate on the soil until the rainy season begins, allowing fungal mycelia to grow, explaining the unpredictable behavior of the mycota (Bärlocher 1992). Therefore, the existence of mycota with different species composition, even in the same climatic seasons, seems more understandable.

The occurrence of aquatic Hyphomycetes at the collection sites - The total numbers of fungal taxa were lowest (seven) at site 5, a drainage canal, and, surprisingly, at site 4, the Lago do Castelinho, formally characterized as meso-oligotrophic (table 5). However, the intense proliferation of Gonapodya and Sapromyces, besides the occurrence of cyanobacteria in the leaf samples, may be considered as evidence that the water could have been contaminated by sewage.

The highest number of taxa, 12, occurred at site 6 (Lago da Roda), with lentic and mesotrophic waters, followed by 11 taxa at site 3 (Canal), with lotic and eutrophic waters (table 5).

Anguillospora crassa, Camposporium pellucidum, Tetrachaetum elegans and Lunulospora curvula occurred at almost all collection sites (table 5). The comparison between the monthly isolated mycota by Sörensen index indicated similarities of 42 and 83\% (table 6). The highest similarity index in the comparison of the mycota occurred between site 5 (Drainage canal) and site 4 (Lago do Castelinho), and site 1 (Lago das Garças), having high trophic levels or unknown water contamination. On the other hand, the lowest similarity index, corresponding to $42 \%$, was obtained by comparison between mycota of site 2 (stream in riparian forest), site 7 (Lago dos Bugios) and site 9 (Lago das Ninféias), as well as the mycota in site 1 (Lago das Garças) and site 10, an artificial waterfall.

Although the total number of taxa was very close, 18 in lentic and 19 in lotic waters, the mycota had a similarity of $68 \%$, probably due to differences in species composition.

Comparing the fungal community according to the eutrophication levels of the waters (table 5), it was observed that 15 taxa were present in eutrophic and also in oligotrophic waters, and 18 taxa in mesotrophic waters. The mycota of the eutrophic and 
Revista Brasil. Bot., V.32, n.3, p.411-426, jul.-set. 2009

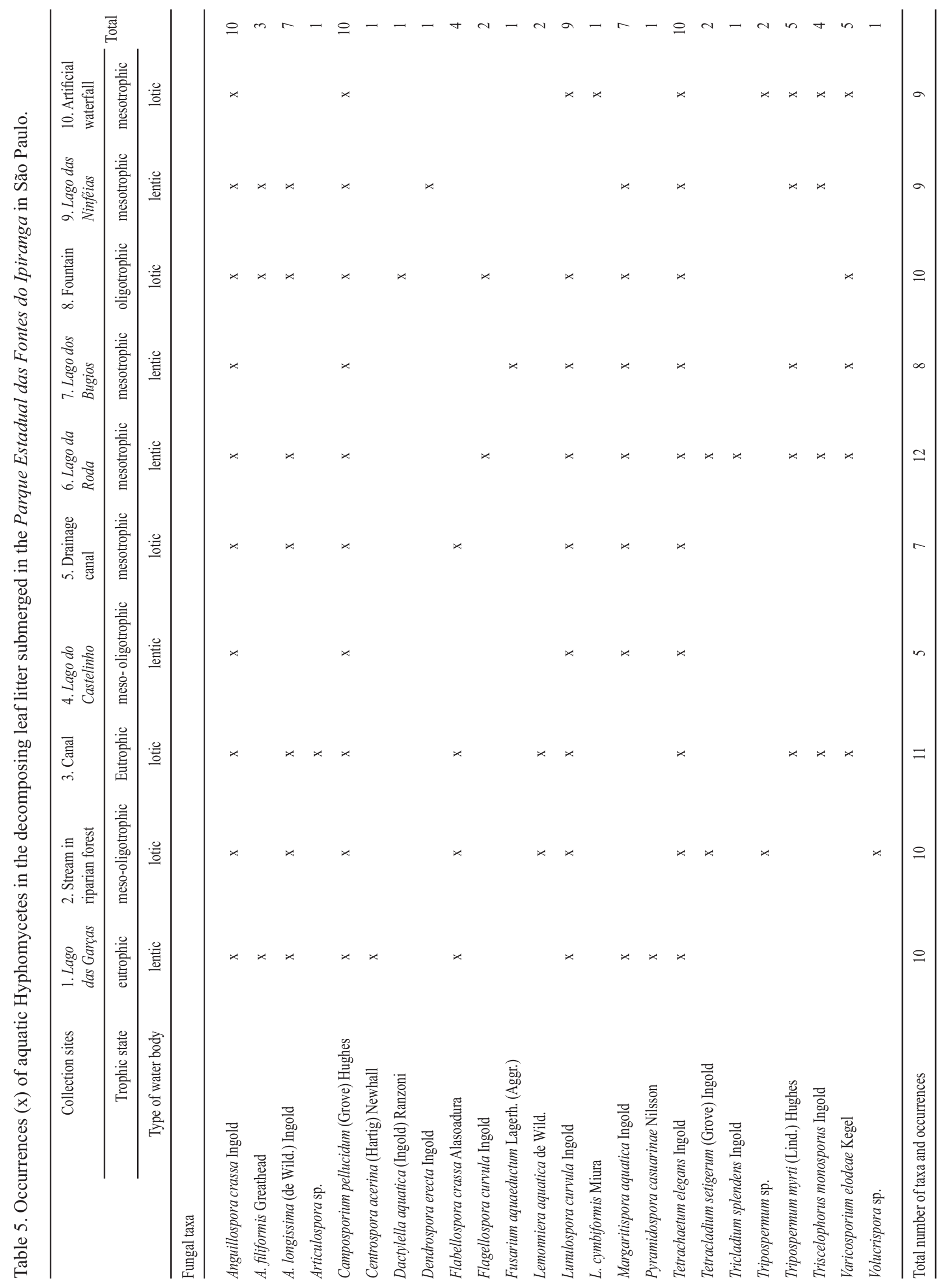




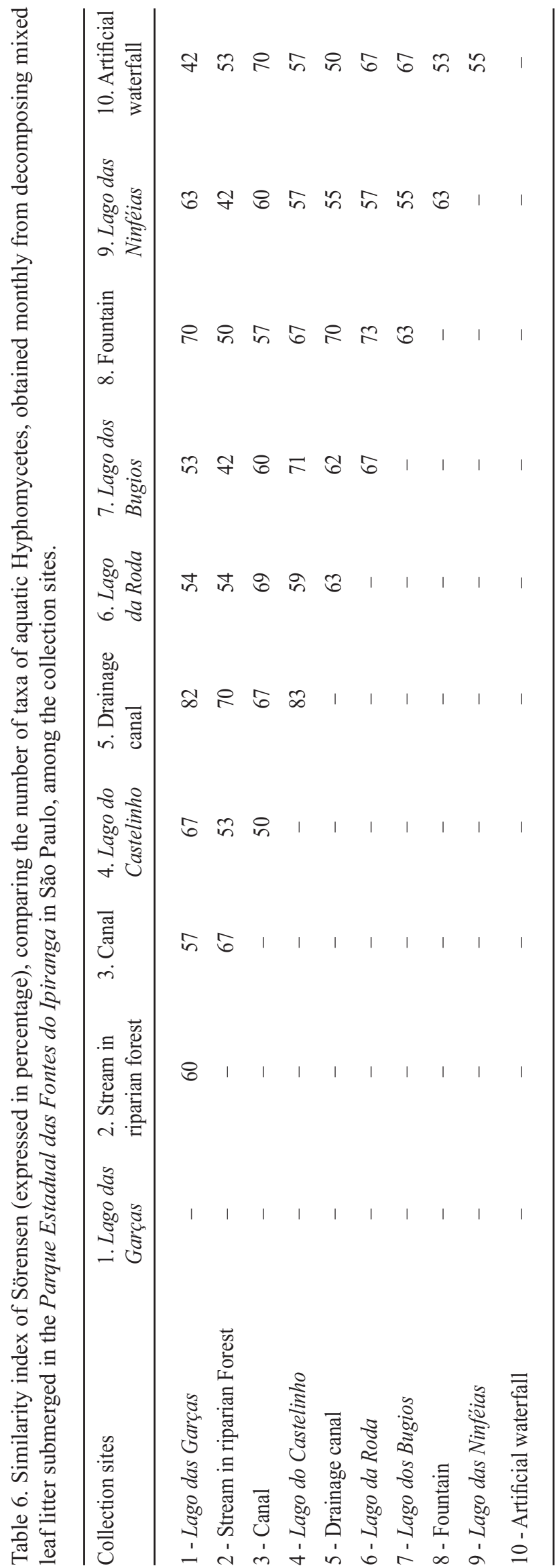

oligotrophic waters were $67 \%$ similar, the mycota of oligotrophic and mesotrophic waters, $70 \%$, and the mycota of eutrophic and mesotrophic waters revealed a similarity of $65 \%$. Articulospora sp., C. acerina and $P$. casuarinae occurred exclusively in eutrophic waters, while D. aquatica and Volucrispora sp., in oligotrophic waters. D. erecta, F. aquaeductum, L. cymbiformis and T. splendens exclusively in mesotrophic waters, indicating that the increase of waters' eutrophication level may decrease similarity between the fungal communities, probably due to the presence of species able to colonize submerged leaves even in highly polluted conditions.

Abiotic factors measured in the water of the collection sites - The highest values of water temperature (from $20.00{ }^{\circ} \mathrm{C}$ to $26.60{ }^{\circ} \mathrm{C}$ ) were registered in February and March of 2005 , and the lowest (from $14.10^{\circ} \mathrm{C}$ to $16.37^{\circ} \mathrm{C}$ ) in July of 2004 (table 7).

The values of water temperature during the collections are comparable to those found in earlier studies conducted in the PEFI reservation. Biesemeyer (2005) cited temperatures between $20.1{ }^{\circ} \mathrm{C}$ to $25.9{ }^{\circ} \mathrm{C}$, and Fonseca (2005) measured values ranging from $16.6{ }^{\circ} \mathrm{C}$ to $23.2^{\circ} \mathrm{C}$. Water temperature was measured in the present study at edges of the water bodies at the same place where the leaf samples were taken, presenting only discrete variation between the collection sites. The water temperature in the PEFI reservation may be considered adequate for fungi, since most aquatic species are mesophilic, with optimal growth at $20^{\circ} \mathrm{C}$ to $25^{\circ} \mathrm{C}$, but tolerating extreme conditions between $5^{\circ} \mathrm{C}$ to $35^{\circ} \mathrm{C}$ (Dix \& Webster 1995). Aquatic Hyphomycetes usually have optimal growth at $15{ }^{\circ} \mathrm{C}$ to $25^{\circ} \mathrm{C}$ (Ingold 1975), presenting possible different sporulation rates at $15^{\circ} \mathrm{C}, 20^{\circ} \mathrm{C}$ or $25^{\circ} \mathrm{C}$ (Chauvet \& Suberkropp 1998).

Regarding collection sites' water $\mathrm{pH}$, the lowest values (between 3.36 to 6.88 ) have been measured mainly in the rainy season, in January and February of 2005 (table 7). Maximum values (5.80 to 9.08) tended to occur in colder and drier months such as May, June and July in 2004, with variations comparable with earlier measurements mentioned in literature (Biesemeyer 2005, Bicudo et al. 2002). The $\mathrm{pH}$ tended to be higher at site 1 (Lago das Garças) than elsewhere, probably due to high photosynthetic activity of phytoplanctonic organisms, decreasing free $\mathrm{CO}_{2}$ and, consequently, increasing $\mathrm{pH}$ (Bicudo et al. 2002).

Higher dissolved oxygen levels (4.85 to $10.78 \mathrm{mg} \mathrm{O}_{2} \mathrm{~L}^{-1}$ ) were measured in the colder and 
Table 7. Maxima and minima of some abiotic factors measured in the water at the collection sites in the Parque Estadual das Fontes do Ipiranga, in São Paulo, from May 2004 to April 2005.

\begin{tabular}{|c|c|c|}
\hline Abiotic factors & Collection sites & Maxima and minima \\
\hline \multirow{10}{*}{ Temperature ${ }^{\circ} \mathrm{C}$} & 1 & $26.60($ Feb./2005) - 15.20 (Jul./2004) \\
\hline & 2 & 17.35 (Nov./2004) - 12.90 (Jul./2004) \\
\hline & 3 & 25.30 (Feb. and Mar./2005) - 16.37 (May/2004) \\
\hline & 4 & 21.10 (Mar./2005) - 13.40 (Jul./2004) \\
\hline & 5 & $20.80($ Mar./2005) - 15.90 (Jul./2004) \\
\hline & 6 & $21.80(\mathrm{Mar} / 2005)-14.40(\mathrm{Jul} . / 2004)$ \\
\hline & 7 & $21.20(\mathrm{Mar} . / 2005)-12.60(\mathrm{Jul} . / 2004)$ \\
\hline & 8 & $20.00($ Mar./2005) - 14.50 (Jul./2004) \\
\hline & 9 & $23.50($ Mar./2005) - 14.10 (Jul./2004) \\
\hline & 10 & 25.50 (Fev./2005) - 14.20 (Jul./2004) \\
\hline \multirow{10}{*}{$\mathrm{pH}$} & 1 & 9.08 (Oct. and Nov./2004) - 6.88 (Jun./2004) \\
\hline & 2 & 7.50 (Jul./2004) - 6.60 (Aug./2004) \\
\hline & 3 & $8.94($ Sep./2004) $-6.12($ Feb./2005) \\
\hline & 4 & $7.64(\operatorname{Jun} . / 2004)-4.88(\operatorname{Jan} . / 2005)$ \\
\hline & 5 & $6.24($ Sep./2004) -4.48 (Dec./2004) \\
\hline & 6 & $5.80(\mathrm{Jul} . / 2004)-4.72(\mathrm{Jan} . / 2005)$ \\
\hline & 7 & $7.67($ Apr./2005) - $3.36(\mathrm{Jan} . / 2005)$ \\
\hline & 8 & $5.94(\mathrm{May} / 2004)-4.00(\mathrm{Jan} . / 2005)$ \\
\hline & 9 & $6.59($ May/2004) $-4.75(\operatorname{Jan} . / 2005)$ \\
\hline & 10 & $6.87($ May/2004) - 4.66 (Jan./2005) \\
\hline \multirow{10}{*}{$\begin{array}{l}\text { Dissolved Oxygen } \\
\mathrm{mg} \mathrm{O}_{2} \mathrm{~L}^{-1}\end{array}$} & 1 & $10.78(\operatorname{Jan} . / 2005)-0.74$ (Jun./2004) \\
\hline & 2 & $10.12($ May/2004) - 5.60 (Nov./2004) \\
\hline & 3 & 10.53 (Jan./2005) - 0.88 (Jun./2004) \\
\hline & 4 & 7.00 (Jul./2004) - 2.70 (Jun./2004) \\
\hline & 5 & 4.85 (Dec./2004) - 0.56 (Apr./2005) \\
\hline & 6 & 7.60 (May/2004) - 1.95 (Oct. and Nov./2004). \\
\hline & 7 & $5.76($ May/2004) - 1.10 (Oct. and Nov./2004) \\
\hline & 8 & $5.71(\mathrm{May} / 2004)-1.29($ Jun./2004) \\
\hline & 9 & $5.43($ May/2004) $-0.83($ Oct. and Nov./2004) \\
\hline & 10 & 6.46 (Aug./2004) - 1.25 (Oct. and Nov./2004) \\
\hline \multirow{10}{*}{$\begin{array}{l}\text { Conductivity } \\
\mu \mathrm{S} \mathrm{cm}^{-3}\end{array}$} & 1 & 195.30 (Jun./2004) - 0.020 (Sep./2004) \\
\hline & 2 & $25.09($ May/2004) - 0.023 (Aug./2004) \\
\hline & 3 & $169.30(\mathrm{May} / 2004)-0.019($ Sep./2004) \\
\hline & 4 & $52.20($ Jun./2004) -0.040 (Jul. and Aug./2004) \\
\hline & 5 & 51.59 (Jun./2004) - 0.006 (Oct. and Nov./2004) \\
\hline & 6 & 25.44 (Jun./2004) - 0.022 (Aug./2004) \\
\hline & 7 & 31.39 (May/2004) - 0.02 (Aug./2004) \\
\hline & 8 & 30.90 (Jun./2004) - 0.028 (Aug./2004) \\
\hline & 9 & $41.50($ May/2004) - 0.035 (Aug. and Sep./2004) \\
\hline & 10 & $42.76($ May/2004) -0.035 (Aug./2004) \\
\hline
\end{tabular}


drier months from May to August 2004, and at the most eutrophicated collection sites too (table 7), except for sites 1, 3 and 4, where higher amounts of dissolved oxygen in water were measured in warmer, rainy months. The frequent blooms of cyanobacteria in some of the water bodies of PEFI reservation such as site 1 (Lago das Garças), with high increases in photosynthetic activity (Bicudo et al. 2002), may justify these results.

Regarding water conductivity, no tendency was clearly defined to justify the variations of the measured values. Higher values of water conductivity were found between May and June, and lower values in August and September of 2004 (table 7). Eutrophic waters usually have higher conductivity because of a greater ionic concentration (Esteves 1998), explaining the occurrence of maximum conductivity values in the waters of sites 1 and 3 (table 7).
The interaction of abiotic factors and the occurrence of aquatic hyphomycetes - To compare abiotic factors and fungal occurrences that had been obtained concomitantly during at least 12 months, the period between May 2004 and April 2005 was considered for multivariate analysis.

In order to evaluate the main tendencies of the abiotic factors in relation to collection sites and the seasons (cold dry season and warm rainy season), a principal component analysis (PCA) was performed. Firstly, the analysis was conducted using only abiotic data excluding fungal data. $88 \%$ of data variability were captured by two first axes (figure 1). The main axis $1(55.2 \%)$ presented higher correlation with $\mathrm{pH}$ $(r>0.9)$ and dissolved oxygen $(r>0.9)$ in water. Axis $2(32.8 \%)$ is positively correlated with water temperature $(r>0.8$ and negatively with water conductivity $(r>-0.7)$.

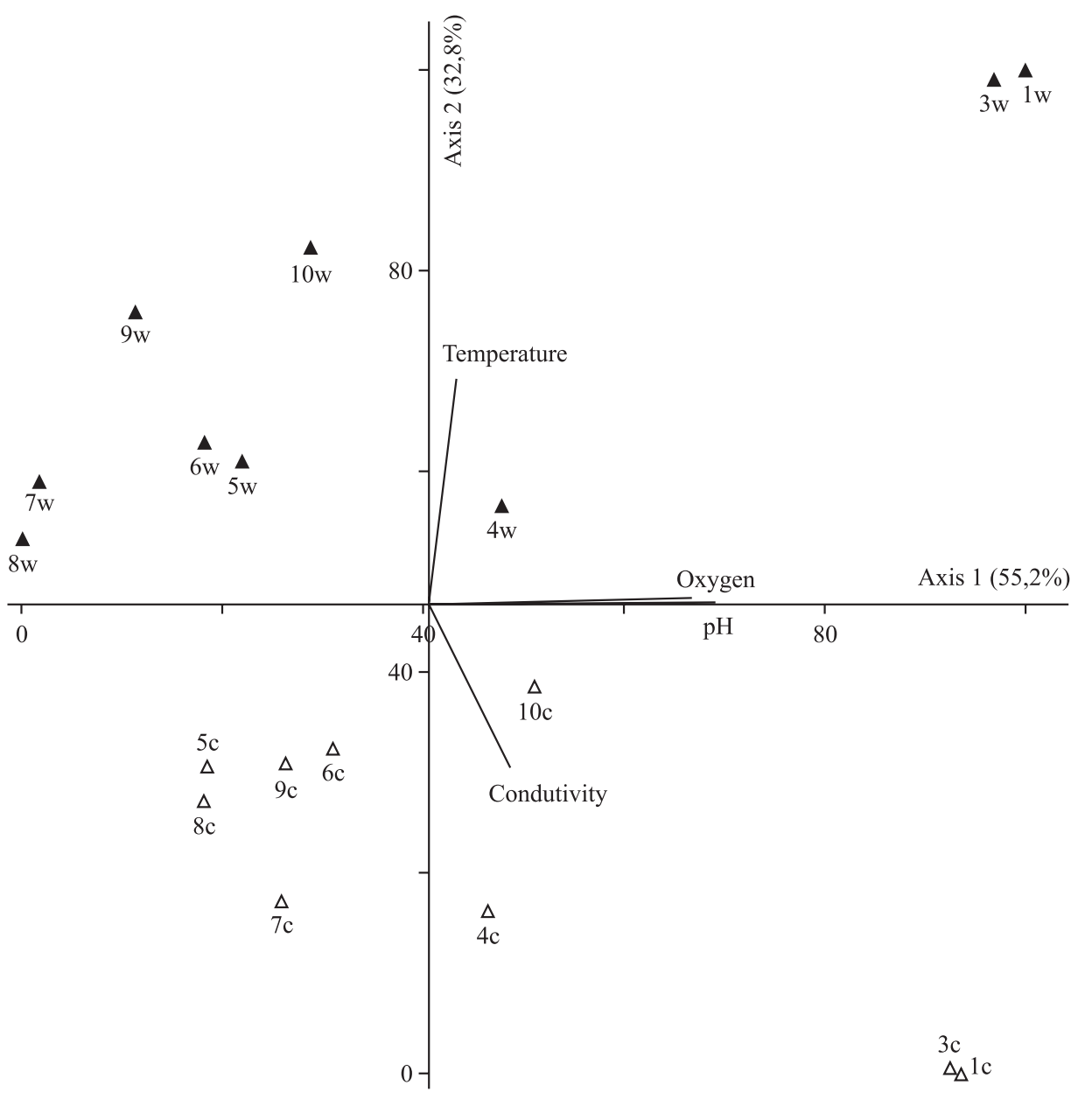

Figure 1. Biplot of PCA for mean values of abiotic factors measured at the collection sites, during the experiment period. Abreviation: $\mathrm{C}=$ cold and dry season and $\mathrm{W}=$ warm and rainy season. Numbers following variables indicate each of the collection site. Treatments: $\boldsymbol{\Delta}=$ warm and rainy season; $\Delta=$ cold and dry season. 
On axis 1 , the sample units were separated by eutrophication level of the collection sites. The sample units taken from site 1 (Lago das Garças) accumulate on the right side of the axis, positively correlating with higher $\mathrm{pH}$ and dissolved oxygen. Besides, the sample units collected from the less eutrophicated sites are ordered on the right side of the axis, next to zero value, and on the left side of the axis. The opposite occurred with the sample units collected from site 8 (Fountain) and site 9 (Lago das Ninféias) during the warm, rainy season, as well as the sample units taken from site 8 (Fountain tank) and site 6 (Lago da Roda) during the cold dry season.

Axis 2 clearly separates the two seasons. The sample units taken during the warm, rainy season are ordered on the upper side of the axis, being positively correlated with temperature $(r>0.3)$ in consequence of the warmer months of the year, and negatively correlated with conductivity $(r>0.5)$, probably due to longer rainfall and diluted ion concentrations in water. Consequently, the sample units taken during the cold dry season are concentrated on the negative side of the axis, being positively correlated with conductivity and negatively with water temperature. This can be observed by the negative correlation expressed by sample units collected from sites 1 and 3 during different seasons, placed on opposite sides of the figure in relation to the axis 2, as well as by the greater clustering of sample units taken during the cold dry season, due to closer correlation between them.

The abiotic data were then analysed with the inclusion of the number of fungal occurrences (figure 2). Two axes account for $81.7 \%$ of data variability. Most of the variability are explained by the first axis (54\%). On the left of this component, all sample units of the eutrophic were ordered, regardless to the seasons:

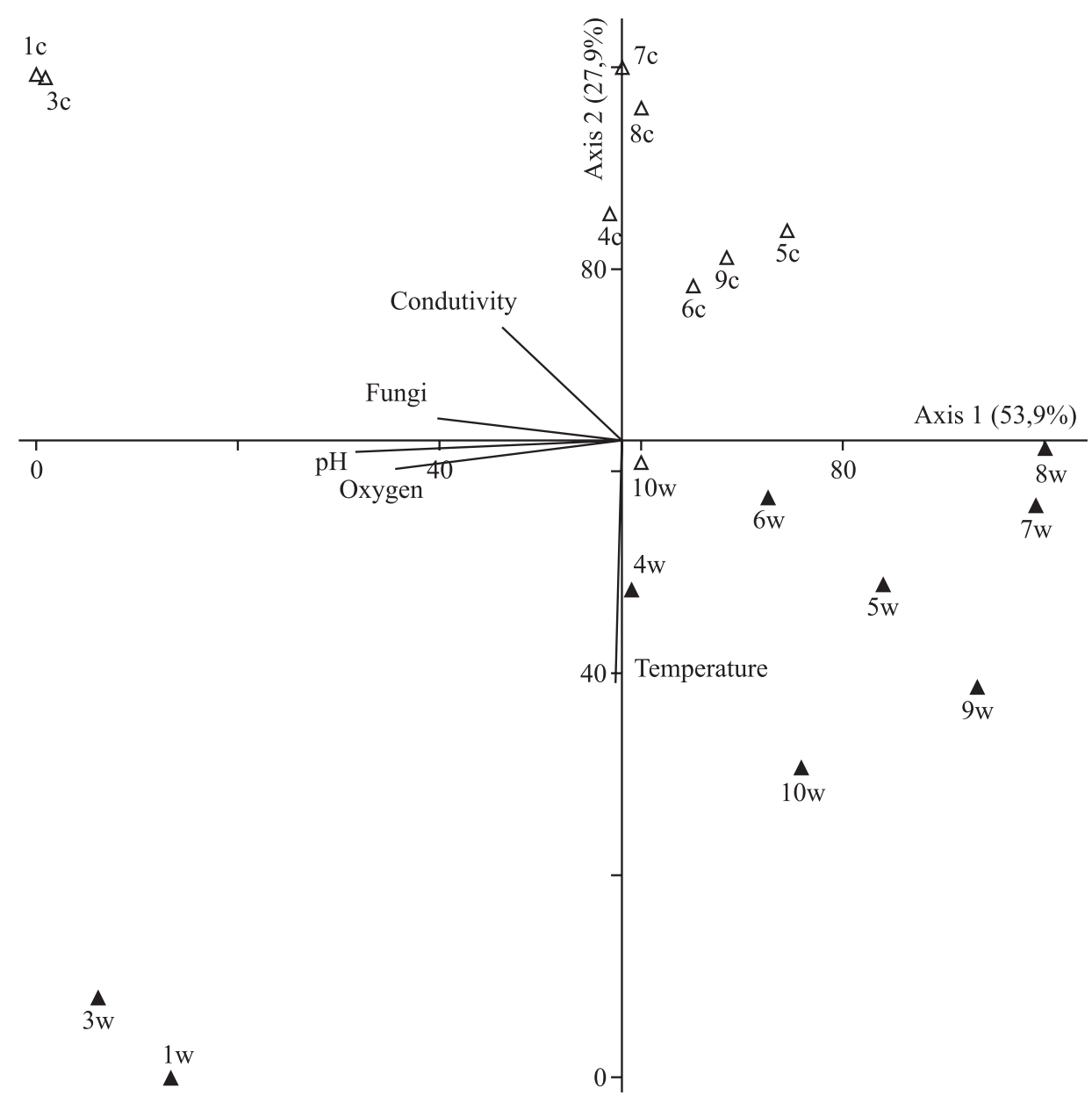

Figure 2. Biplot of PCA for mean values of abiotic factors and fungal occurrences at the collection sites, during the experiment period. Abreviation: $\mathrm{C}=$ cold and dry season and $\mathrm{W}=$ warm and rainy season. Numbers following variables indicate each collection site. Treatments: $\Delta=$ warm and rainy season; $\Delta=$ cold and dry season. 
Lago das Garças - site 1; 1C (site 1, cold and dry season), $1 \mathrm{~W}$ (site 1, warm rainy season); Canal - site 3; $3 \mathrm{C}$ (site 3, cold dry season), $3 \mathrm{~W}$ (site 3, warm rainy season), correlated to higher $\mathrm{pH}(r>-0.9)$, dissolved oxygen $(r>-0,8)$, fungal occurrences $(r>-0.7)$ and conductivity $(r>-0.6)$. On the right side of the axis, all remaining sample units (except those taken from site 4) are ordered, mainly during the warm rainy season, being inversely correlated to the above-mentioned factors. On axis 2, the sample units were ordered by climatic season. Thus, the samples taken during the warm rainy season accumulate on the negative side of this axis, being associated with higher temperature $(r>-0.8)$ and lower conductivity $(r>0.6)$. On the other hand, the samples collected during the cold dry season accumulate on the positive side of the axis.

Probably due to their sensitivity to decreased oxygen levels in the water, at a first view, the aquatic Hyphomycetes seem to be bioindicators to attest water quality, however their ability to metabolize dissolved organic matter and to survive using inorganic nutrients (Gessner 1997) may explain conflicting results of pollution studies. For instance, in two surveys, Greathead (1961) and Conway (1970) reported a drastic decrease of the number of aquatic Hyphomycetes in streams contaminated with domestic sewage. Sládecková (1963) reported an increase of the diversity of aquatic Hyphomycetes on leaves submerged in a stream polluted by starch effluents. Burgos \& Castillo (1986) compared the fungal colonization of leaves in streams at sites above and below an organic pollution source, verifying that all leaves at the clean sites were colonized by 17 species, whereas at the polluted sites $2.5 \%$ of the leaves were colonized by only four species. On the other hand, Suberkropp et al. (1988) did not observe any effects of the effluents rich in phosphates, organic matter and nitrogen compounds on the community structure of aquatic Hyphomycetes.

Following the fungal succession during the decomposition of leaves of Ficus microcarpa submerged in the eutrophic Lago das Garças lake, Schoenlein-Crusius \& Milanez (1989) observed some Ingoldian fungi, which were latter reported in mesotrophic or oligotrophic waters, such as streams in the atlantic rainforest of Paranapiacaba (SchoenleinCrusius et al. 1992).

In the present study, a greater variability of abiotic factors can be considered as caused by water's trophic levels on the sites (axis 1), followed by the climatic and seasonal influence (axis 2). The occurrence of aquatic Hyphomycetes was mainly conditioned by the water's trophic levels on the sites, regardless of season, reinforcing the necessity to continue the monitoring and recovering procedures of the aquatic environments in the PEFI reservation, before the diversity of the aquatic mycota is be irreversible compromised.

Acknowledgments - to CNPq (Conselho Nacional para o Desenvolvimento da Pesquisa) for the fellowship to the first author (CNPq, process n $\left.{ }^{\circ} 301311 / 2003-0\right)$.

\section{References}

ALEXOPOULOS, C.J., MIMS, C.W. \& BLACKWELL, M. 1996. Introductory mycology. $4^{\text {th }}$ ed., John Wiley \& Sons Inc., New York.

AU, D.W.T., HODKISS, I.J. \& VRIJMOED, L.L.P. 1992. Fungi and cellulolytic activity with decomposition of Bauhinia purpurea leaf litter in a polluted and unpolluted Hong Kong waterway. Canadian Journal of Botany 70:1071-1079.

BÄRLOCHER, F. 1992. Research on aquatic Hyphomycetes: historical background and overview. In The ecology of aquatic Hyphomycetes (F. Bärlocher, ed.). Springer Verlag, Berlin, p.1-15.

BARROS, F., MAMEDE, M.C.H., MELO, M.M.R.F., LOPES, E.A., JUNG-MENDAÇOLLI, S.L., KIRIZAWA, M., MUNIZ, C.F.S., MAKINOWATANABE, H., CHIEA, S.A.C. \& MELHEM, T.S.A. 2002. A Flora fanerogâmica do PEFI: composição, afinidades e conservação. In Parque Estadual das Fontes do Ipiranga (PEFI): unidade de conservação que resiste à urbanização de São Paulo (D.C. Bicudo, M.C. Forti \& C.E.M. Bicudo, eds.). Editora Secretaria do Meio Ambiente do Estado de São Paulo, São Paulo, p.95-110.

BICUDO, D.C., FORTI, M.C. \& BICUDO, C.E.M. (eds.). 2002. Parque Estadual das Fontes do Ipiranga (PEFI): unidade de conservação que resiste à urbanização de São Paulo. Editora Secretaria do Meio Ambiente do Estado de São Paulo, São Paulo.

BIESEMEYER, K.F. 2005. Variação nictemeral da estrutura e dinâmica da comunidade fitoplanctônica em função da temperatura da água nas épocas de seca e chuva em reservatório urbano raso mesotrófico (Lago das Ninféias), Parque Estadual das Fontes do Ipiranga, São Paulo. Dissertação de mestrado, Instituto de Botânica, São Paulo.

BURGOS, E.J. \& CASTILLO, P.H. 1986. Hyphomycetes acuaticos como indicadores de contaminacion. Biota $2: 1-10$

CHAUVET, E. \& SUBERKROPP, K. 1998. Temperature and sporulation of aquatic Hyphomycetes. Applied Environmental Microbiology 64:1522-1525. 
CHRISTENSEN, M. 1989. A view of fungal ecology. Mycologia 81:1-19.

CONWAY, K.E. 1970. The aquatic Hyphomycetes of central New York. Mycologia 62:516-530.

DEL FRATE, G. \& CARETTA, G. 1983. Aquatic Hyphomycetes of a mountain stream in Valesia (Piemonte). Hydrobiologia 102:69-71.

DIX, N. J. \& WEBSTER, J. 1995. Fungal ecology. Chapman \& Hall, Cambridge.

ESTEVES, F.A. 1998. Fundamentos da Limnologia. Editora Interciência, Rio de Janeiro.

FERNANDES, A.J., REIS, L.A.M. \& CARVALHO, A. 2002. Caracterização do meio físico. In Parque Estadual das Fontes do Ipiranga (PEFI): unidade de conservação que resiste à urbanização de São Paulo (D.C Bicudo, M.C. Forti \& C.E.M. Bicudo, eds.). Editora Secretaria do Meio Ambiente do Estado de São Paulo, São Paulo, p.51-62.

FERREIRA, J.C., SINCLAIR, R.C. \& EICKER, A. 1981. The aquatic Hyphomycetes of the Apies River, South Africa. South African Journal of Botany 47:49-55.

FONSECA, B.M. 2005. Diversidade fitoplanctônica como discriminador ambiental em dois reservatórios rasos com diferentes estados tróficos no Parque Estadual das Fontes do Ipiranga, São Paulo, SP. Tese de doutorado, Universidade de São Paulo, São Paulo.

GESSNER, M.O. 1997. Fungal biomass, production and sporulation associated with particulate organic matter in streams. Limnetica 13:33-44.

GREATHEAD, S.K. 1961. Some aquatic Hyphomycetes in South Africa. South African Journal of Botany 27:195228.

INGOLD, C.T. 1975. An illustrated guide to aquatic and water-borne Hyphomycetes (Fungi Imperfectiwith notes on their biology). Freshwater Biological Association, Ambleside, Cumbria. Scientific Publication n.30.

IQBAL, S.H. \& BHATTY, S.F. 1979. Conidia from stream foam. Transactions of the Mycological Society of Japan 20:83-91.

IQBAL, S.H. \& WEBSTER, J. 1977. Aquatic hyphomycete spora of some Dartmoor streams. Transactions of the British Mycological Society 69:233-241.

KIRK, P.M., CANNON, P.F., DAVID, J.C. \& STALPERS, J.A. 2001. Ainsworth \& Bisby's Dictionary of the fungi. $9^{\text {th. }}$ ed. CAB International, Oxford University Press, Oxford.

MARVANOVÁ, L. 1997. Freshwater Hyphomycetes: a survey with remarks on tropical taxa. In Tropical mycology (K.K. Janardhanan, C. Rajendran, K. Natarajan \& D.L. Hawksworth, eds.) Science Publishers, Inc., New Hampshire, p.169-226.

MILANEZ, A.I. \& TRUFEM, S.F.B. 1984. Fungos zoospóricos em frutos submersos do Parque Estadual das Fontes do Ipiranga, São Paulo, 2. Rickia 11:77-84.
MILANEZ, A.I. PIRES-ZOTTARELLI, C.L.A. \& SCHOENLEIN-CRUSIUS, I.H. 1996. Criptógamos do Parque Estadual das Fontes do Ipiranga, São Paulo, SP. Fungos 5: Leptomitales (Rhipidiaceae). Hoehnea 23:67-76.

MORAES, R.M. 2002. Ciclagem de nutrientes na floresta do PEFI: produção e decomposição da serapilheira. In Parque Estadual das Fontes do Ipiranga (PEFI): unidade de conservação que resiste à urbanização de São Paulo (D.C. Bicudo, M.C. Forti \& C.E.M. Bicudo, eds.). Editora Secretaria do Meio Ambiente do Estado de São Paulo, São Paulo, p.135-142.

MÜlLER-DOMBOIS, D. \& ELLENBERG, H. 1974. Mathematical treatment of vegetation data. Aims and methods of vegetation ecology. John Wiley \& Sons., New York, p.211-302.

NASTRI, V.D.F., CATHARINO, E.L.M., ROSSI, L., BARBOSA, L.M., PIRRÉ, E., BEDINELLI, C., ASPERTI, L.M., DORTA, R.O. \& COSTA, M.P. 1992. Estudos fitossociológicos em uma área do Instituto de Botânica de São Paulo utilizados em programas de educação ambiental. In Anais do II Congresso Nacional sobre Essências Nativas. Revista do Instituto Florestal 4:219-225.

NILSSON, S. 1964. Freshwater Hyphomycetes. Symbolae Botanica Upsalienses 18:1-130.

PIRES-ZOTTARELLI, C.L. \& ROCHA, M. 2007. Novas citações de Chytridiomycota e Oomycota para o Parque Estadual das Fontes do Ipiranga (PEFI), SP, Brasil. Acta Botanica Brasilica 21:125-136.

PIRES-ZOTTARELLI, C.L.A., MILANEZ, A.I., SCHOENLEIN-CRUSIUS, I.H. \& LOHMANN, L.G. 1996. Criptógamos do Parque Estadual das Fontes do Ipiranga, São Paulo, SP. Fungos, 6: Chytridiales. Hoehnea 23:77-90.

SANTOS, P.M. \& FUNARI, F.L. 2002. Clima local. In Parque Estadual das Fontes do Ipiranga (PEFI): unidade de conservação que resiste à urbanização de São Paulo (D.C. Bicudo, M.C. Forti \& C.E.M. Bicudo, eds.). Editora Secretaria do Meio Ambiente do Estado de São Paulo, São Paulo, p.41-48.

SCHOENLEIN-CRUSIUS,I.H.2002.AquaticHyphomycetes from cerrado regions in the state of São Paulo, Brazil. Mycotaxon 81:457-462.

SCHOENLEIN-CRUSIUS, I.H. \& GRANDI, R.A.P. 2003. The diversity of aquatic Hyphomycetes in South America. Brazilian Journal of Microbiology 34:183193.

SCHOENLEIN-CRUSIUS, I.H. \& MALOSSO, E. 2007. Diversity of aquatic Hyphomycetes in the Tropics. In Fungi: multifaceted microbes (B.N. Ganguli \& S.K. Deshmukh eds.). Anamaya Publishers, New Delhi, p.61-81. 
SCHOENLEIN-CRUSIUS, I.H. \& MILANEZ, A.I. 1989. Sucessão fúngica em folhas de Ficus microcarpa L. f. submersas no Lago Frontal situado no Parque Estadual das Fontes do Ipiranga, São Paulo. Revista de Microbiologia 20:95-101.

SCHOENLEIN-CRUSIUS, I.H. \& MILANEZ, A.I. 1998. Fungos microscópicos da Mata Atlântica de Paranapiacaba, São Paulo, Brasil. Revista Brasileira de Botânica 21:73-79.

SCHOENLEIN-CRUSIUS, I.H., PIRES-ZOTTARELLI, C.L.A. \& MILANEZ, A.I. 1992. Aquatic fungi in leaves submerged in a stream in the Atlantic Rainforest. Revista de Microbiologia 23:167-171.
SLÁDECKOVÁ, A. 1963. Aquatic deuteromycetes as indicators of starch campaign pollution. Internationale Revue der Gesamte Hydrobiologie 48:35-42.

SUBERKROPP, K., MICHELIS, A., LORCH, H.J. \& OTTOW, J.C.G. 1988. Effect of sewage treatment plant effluents on the distribution of aquatic Hyphomycetes in the River Erms, Schwäbische Alb, F.R.G. Aquatic Botany 32:141-153.

SUBRAMANIAN, C.V. 1983. Hyphomycetes. Taxonomy and biology. Academic Press, London.

WEBSTER, J.\& DESCALS, E. 1981. Morphology, distribution and ecology of conidial fungi in freshwater habitats. In Biology of Conidial Fungi (G.T. Cole \& B. Kendrick, eds.). Academic Press, New York, v.1, p.295-355. 